\title{
Zooplankton as a potential vector of diarrhetic shellfish poisoning toxins through the food web
}

\author{
I. Maneiro ${ }^{1, *}$, M. Frangópulos ${ }^{1}$, C. Guisande ${ }^{1}$, M. Fernández ${ }^{2}$, B. Reguera $^{3}$, I. Riveiro ${ }^{1}$ \\ ${ }^{1}$ Facultad de Ciencias del Mar, Universidad de Vigo, Aptdo. 874, 36200 Vigo, Spain \\ ${ }^{2}$ Laboratorio de Sanidad Exterior de Vigo, European Community Reference Laboratory on Marine Biotoxins, \\ Estación Marítima s/n, 36271 Vigo, Spain \\ ${ }^{3}$ Instituto Español de Oceanografía, Centro Costero de Vigo, Aptdo. 1552, 36280 Vigo, Spain
}

\begin{abstract}
This study was carried out during an autumn bloom of Dinophysis acuminata in the Galician Rías Bajas (NW Spain). The main objective was to determine whether any of the predominant zooplankton species could ingest and transfer toxins through the pelagic food web. Grazing experiments showed that the copepods Temora longicornis and Oithona nana and the tintinnid Favella serrata fed on Dinophysis spp. whereas the copepods Acartia clausi and Euterpina acutifrons did not. However, only F. serrata seem to profit from the ingestion of the toxic dinoflagellates. Field populations of $F$. serrata increased whereas $T$. longicornis and $O$. nana densities declined after the toxic outbreak. Okadaic acid content found in the seston size fractions 100-200, 200-300 and 300-1000 $\mu \mathrm{m}$ showed a good correlation with F. serrata. These results confirm the hypothesis that tintinnids can transfer dinoflagellates toxins to higher trophic levels in the pelagic food web. The importance of faecal pellets with undigested dinoflagellates as an alternative pathway to transmit toxins to pelagic or benthic organisms is mentioned.
\end{abstract}

KEY WORDS: Zooplankton · Dinoflagellates · Toxins · Dinophysis spp. D DSP $\cdot$ Ingestion rates

\section{INTRODUCTION}

Grazing zooplankton are potential vectors of phytotoxins in the pelagic food web (Turner \& Tester 1997, Turner et al. 1998). Field observations during blooms of dinoflagellates that produce paralytic shellfish poisoning (PSP) toxins (White 1981, Hayashi et al. 1982), and laboratory experiments with cultures of Alexandrium spp., have shown that zooplankton can ingest these toxins and accumulate them in their somatic tissues (Boyer et al. 1985, Turriff et al. 1995, Teegarden \& Cembella 1996). Zooplankton might thus transmit toxins to their predators. Mass mortalities of pelagic fishes such as herring and mackerel (White 1980, 1981, Beaulieu et al. 1996, Montoya et al. 1996, Castonguay et al. 1997) and marine mammals (Geraci et al. 1991,

*E-mail: imaneiro@uvigo.es
Landsberg \& Stidinger 1998) exposed to toxic dinoflagellate or diatom blooms, and accumulation of PSP toxins in anchovies (Montoya et al. 1998), have been reported. In all these cases, zooplankton presumably acted as a link between toxic phytoplankton and higher trophic levels.

However, there is little information about the interactions between zooplankton and phytoplankton that produce diarrhetic shellfish poisoning (DSP) toxins. This is due to the lack of established cultures of Dinophysis, the only phytoplanktonic genus so far known to produce DSP toxins. Dinophysis spp. usually occur at moderate concentrations $\left(10^{2}\right.$ to $10^{3}$ cells $\left.\mathrm{l}^{-1}\right)$, and their effects are not as conspicuous as those caused by dinoflagellates which form dense blooms. There is only one report of fish mortality possibly associated with a dense bloom of Dinophysis caudata in the Seto Inland Sea of Japan (Okaichi 1967), but the cause of the mortality was not established with certainty. 
Dinophysis acuminata Ehrenberg and other Dinophysis spp. are regular components of the phytoplankton in the Galician Rías (NW Spain). They grow every year and render toxic bivalves which leads to closures of harvesting (Reguera et al. 1990, 1995). Maximum concentrations of Dinophysis in the area range from 0.5 to $10^{5}$ cells $\mathrm{l}^{-1}$; here the term 'bloom'

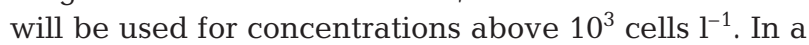
field study, Turner \& Anderson (1983) concluded that despite being the dominant species $D$. acuminata was not eaten by zooplankton. In contrast, Carlsson et al. (1995) reported that $D$. acuminata was grazed by 3 copepod species (Acartia clausi, Isias clavipes and Centropages typicus) in Biscayan waters. Significantly more individuals of $A$. clausi died than of the other copepod species, therefore these authors concluded that the okadaic acid content (OA) of Dinophysis may have deleterious effects on this copepod species. During a field survey carried out to study the interactions between a $D$. acuminata bloom and the microzooplankton community, Maneiro et al. (1998) found that 2 tintinnids, Favella ehrenbergii and Tintinnopsis campanula, co-occurred with the maximal abundance of D. acuminata. This coincidence suggested that there might be a trophic relationship between Dinophysis and the tintinnids.

In this study, the feeding response of the dominant zooplankton species was examined during an autumn bloom of Dinophysis acuminata in the Galician Rías. The main objective was to determine whether any of the dominant zooplankton species were capable of ingesting and accumulating DSP toxins.

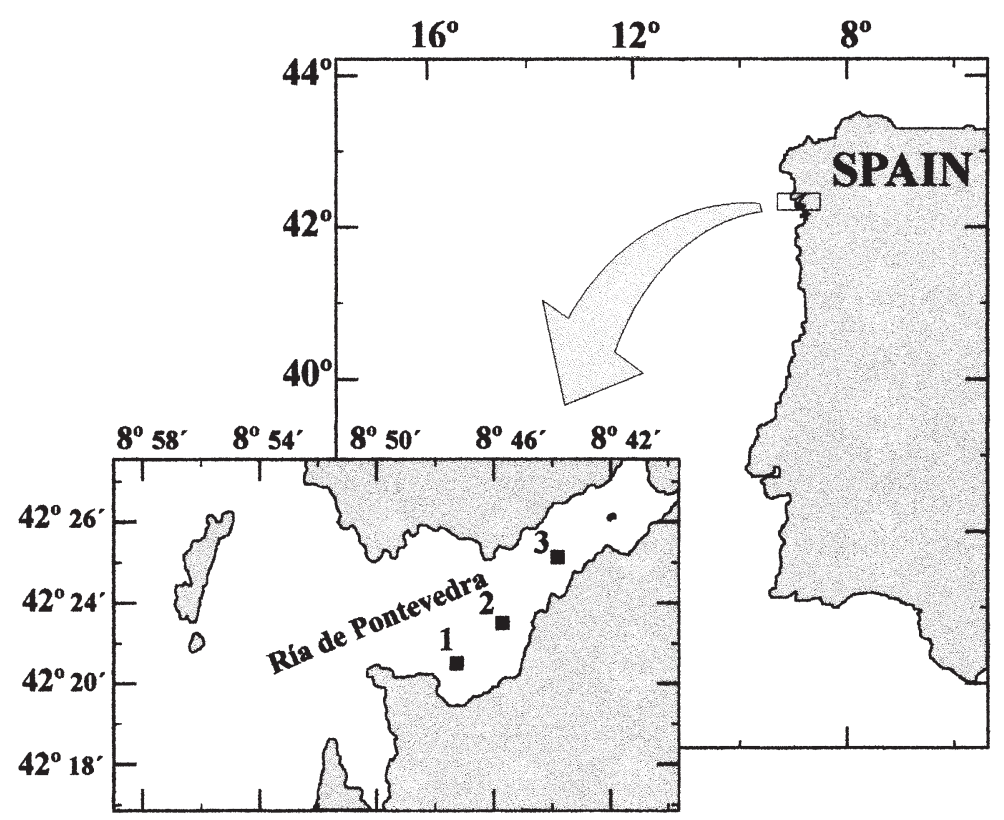

Fig. 1. Map of the Ría de Pontevedra showing location of sampling stations

\section{METHODS}

Field study. Samples were collected weekly during a bloom of Dinophysis spp. from 8 September to 5 October 1998 at 3 stations in Ría de Pontevedra (Fig. 1).

Five litre Niskin bottle casts were made at 2, 5, 10, 15 and $20 \mathrm{~m}$. One litre aliquots from each depth were routinely concentrated with a $20 \mu \mathrm{m}$ mesh net and fixed in Lugol's iodine solution. But when Dinophysis was very common (following results of the local monitoring centre), $100 \mathrm{ml}$ samples were fixed without previous concentration. Cell counts were made with an inverted microscope after sedimentation of 25 to $50 \mathrm{ml}$ samples.

Vertical hauls were made with a Bongo net (opening diameter $23 \mathrm{~cm}, 20 \mu \mathrm{m}$ mesh size) fitted with a 'General Oceanic' flowmeter, from $20 \mathrm{~m}$ to the surface. These samples were divided into 2 aliquots; one was used to estimate toxin content, and the other for analysis of zooplankton composition. Each sample was sieved to obtain 4 different size fractions: 20-100, 100-200, 200-300 and 300-1000 $\mu \mathrm{m}$. Most Dinophysis cells were retained in the 20-100 $\mu \mathrm{m}$ fraction. Samples for zooplankton composition and abundance estimate were preserved in formalin (4\%) neutralised with borax. For the toxin analyses, each of the size fractions was resuspended in $1 \mathrm{l}$ of filtered seawater, and four $75 \mathrm{ml} \mathrm{sub-}$ samples were filtered through a pre-combusted baked glass microfibre filter $(0.72 \mu \mathrm{m}$ mesh size $)$ and immediately frozen for subsequent DSP toxin analyses.

Toxin analyses. Toxins were extracted by sonication (15 min, twice) of the filters with the seston fractions in $2 \mathrm{ml}$ of $80 \%$ methanol. After centrifugation, the supernatant was decanted and the filter was sonicated again with $1 \mathrm{ml}$ of $80 \%$ methanol. Supernatants were combined, and after addition of $1 \mathrm{ml}$ of water to $2.5 \mathrm{ml}$ of the methanol extract, toxins were extracted with $4 \mathrm{ml}$ of chloroform. The chloroform extract was dried with $\mathrm{Na}_{2} \mathrm{SO}_{4}$ and an aliquot was evaporated for HPLC analyses. $200 \mu \mathrm{l}$ of $0.2 \%$ 9-ADAM methanolic solution was added to the dried seston extracts. The mixture was shaken for $2 \mathrm{~min}$ and kept for $1 \mathrm{~h}$ at $40^{\circ} \mathrm{C}$ protected against the light. The ADAM solution was prepared daily from small portions of the reagent kept at $-30^{\circ} \mathrm{C}$ by adding some drops of acetone to facilitate the further solution in methanol, and was then filtered through $0.45 \mu \mathrm{m}$. The clean-up step was identical to that described in Lee et al. (1987). HPLC analysis followed Lee's method (1987) with slight modifications. The fluorescent esters were separated using a Hewlett-Packard 1050 liquid chro- 
matograph in a Merck Supersphere 100 column (LichroCart 250-4) and detected in a Hewlett-Packard 1046A fluorescence detector. The mobile phase was acetonitrile:water 80:20, the column temperature was $35^{\circ} \mathrm{C}$ and the excitation and emision wavelengths were $365 \mathrm{~nm}$ and $412 \mathrm{~nm}$, respectively. The flow rate was $1.1 \mathrm{ml} \mathrm{min}{ }^{-1}$. Okadaic acid from the National Research Council (Canada), DTX1 from Calbiochem and DTX2 (generous gift from Kevin James, Ireland) were used as toxin standards.

Grazing experiments. Phytoplankton and zooplankton samples were collected at Stn 3 on 8 September and at Stn 2 on 22 September. Vertical hauls were carried out from $20 \mathrm{~m}$ depth to the surface with a $20 \mu \mathrm{m}$ mesh net. Samples were transported within $2 \mathrm{~h}$ of collection to the laboratory, and healthy individuals of the dominant zooplankton species were selected under a stereoscopic microscope for grazing experiments. After sieving through a $75 \mu \mathrm{m}$ mesh net to remove grazers, the sample was concentrated on a $20 \mu \mathrm{m}$ mesh and the concentrated material poured into a 11 beaker and incubated at $18^{\circ} \mathrm{C}$ for $2 \mathrm{~h}$. The upper part of the water (approximately $300 \mathrm{ml}$ ) was subsequently siphoned off into a clean $1 \mathrm{l}$ container to select healthy swimming phytoplankton for the grazing experiment and to avoid sediment and unhealthy cells. These cells were then resuspended in $0.45 \mu \mathrm{m}$ Whatman GF/F-filtered seawater to provide Dinophysis concentrations ranging between 1 and $24 \times 10^{3}$ cells l$^{-1}$ for the grazing experiments. Frost's (1972) equations were used to calculate initial $\left(C_{\mathrm{i}}\right)$ and control $\left(C_{\mathrm{x}}\right)$ concentrations, and copepod ingestion rates in experimental containers. Table 1 shows $C_{\mathrm{i}}$ and $C_{\mathrm{x}}$ obtained in both experiments. These concentrations were in the range of Dinophysis abundance observed in the field during the DSP outbreak (Fig. 2).

In the first experiment on 8 September, individuals of Favella serrata and adult females of Temora longicornis were isolated from the sample with a stereoscopic microscope, and groups of $10 \mathrm{~F}$. serrata individuals and $1 \mathrm{~T}$. longicornis were kept in plastic vessels with $20 \mathrm{ml}$ of food suspension. Four replicates were used for each species in each experimental food concentration, and 4 initial trials and 4 controls with food suspension and no zooplankton were used to estimate initial and final phytoplankton concentration, respectively. In the second experiment on 22 September, 6 adult females of Acartia clausi, Euterpina acutifrons and Oithona nana were isolated and placed in individual plastic vessels with $10 \mathrm{ml}$ of experimental food suspension. In both sets of experiments, vessels were kept at $18^{\circ} \mathrm{C}$ in darkness for $12 \mathrm{~h}$. Zooplankton individuals were checked
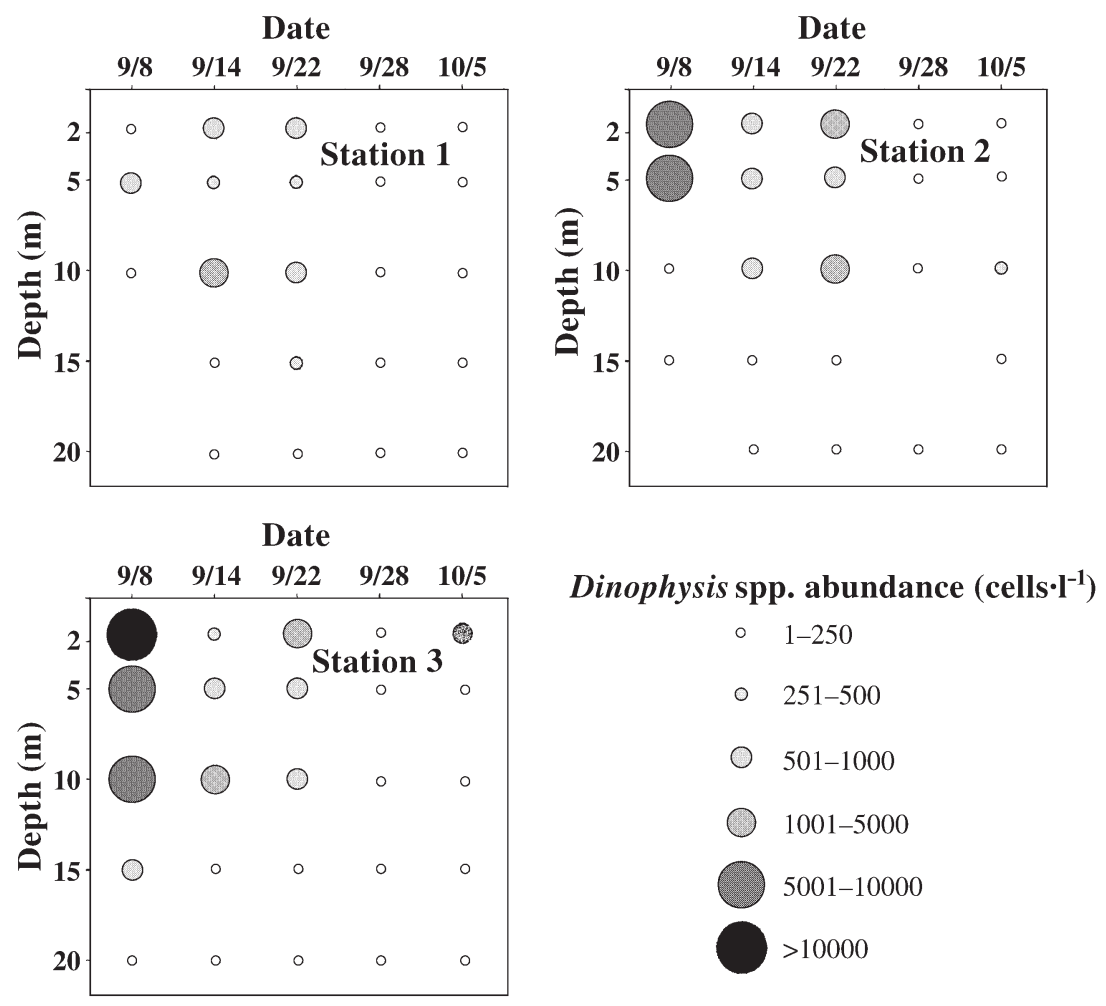

Fig. 2. Vertical distribution of the abundance of Dinophysis spp. (cells $\mathrm{l}^{-1}$ ) in Ría de Pontevedra from 8 September to 5 October (see Fig. 1 for station positions) 
Table 1. Initial concentrations $\left(C_{\mathrm{i}}\right)$ and average cell concentrations $\left(C_{\mathrm{x}}\right)$ of Dinophysis spp. in the grazing experiments $\left(\right.$ mean $\pm \mathrm{SE}$, in cells $\left.\mathrm{l}^{-1}\right)$

\begin{tabular}{|lcc|}
\hline Experimental date & $C_{\mathrm{i}}$ & $C_{\mathrm{x}}$ \\
\hline 9 September & $1600 \pm 73$ & $1337 \pm 41$ \\
& $3846 \pm 87$ & $2486 \pm 223$ \\
& $14091 \pm 891$ & $13751 \pm 473$ \\
& $24666 \pm 1778$ & $27823 \pm 4405$ \\
22 September & $8980 \pm 485$ & $9907 \pm 148$ \\
& $5627 \pm 282$ & $7055 \pm 255$ \\
& $2667 \pm 162$ & $2760 \pm 203$ \\
& $882 \pm 69$ & $969 \pm 47$ \\
& & \\
& & \\
& &
\end{tabular}

with a stereoscopic microscope at the end of the experiment. Samples were collected and preserved in Lugol's iodine for phytoplankton cell counting with an inverted microscope.

Manly's coefficient $\left(\alpha_{i}\right)$ (Manly 1974) was used to measure dietary preference of zooplankton species for Dinophysis spp.:

$$
\alpha_{i}=\frac{\log \frac{e_{i}}{n_{i}}}{\sum_{j=1}^{m} \frac{e_{j}}{n_{j}}}
$$

where $n_{i}$ and $e_{i}$ are the initial and final concentrations of Dinophysis spp. cells, $n_{j}$ and $e_{j}$ are the initial and final numbers of uneaten prey type $j$, and $m$ is the number of phytoplankton species. Thus $\alpha_{i}$ is an estimate of the extent to which Dinophysis is selected.

\section{RESULTS}

Dinophysis acuminata was the predominant Dinophysis spp. during the period of the study with a pooled mean \pm SD considering all stations of $76.5 \pm 18.8$ (range 41.9 to $94.7 \%$ ). D. rotundata and D. Caudata represented a low percentage of total Dinophysis population with a pooled mean \pm SD of $19.2 \pm 16.4$ (range 4.8 to $55.5 \%$ ) and $4.3 \pm 6.6$ (range 0 to $20.4 \%$ ), respectively. Fig. 2 shows Dinophysis spp. abundance in the water column during the sampling period. The highest values of dinoflagellate abundance appeared between 2 and $10 \mathrm{~m}$ at all sampling stations. The maximum cell density was found at Stn 3 on 8 September when $28 \times$ $10^{3}$ cells $\mathrm{l}^{-1}$ were observed at $2 \mathrm{~m}$ depth. Thereafter, dinoflagellate concentration decreased although the cell abundance remained higher than $10^{3}$ cells $\mathrm{l}^{-1}$ in the upper $10 \mathrm{~m}$ on 14 and 22 September. Concentrations decreased (>500 cells $\mathrm{l}^{-1}$ ) on 28 September, and this levels remained until 5 October.

The accompanying phytoplankton populations changed over the sampling period. Fig. 3 shows percentage of the 20-75 $\mu \mathrm{m}$ size fraction phytoplankton species on 8 and 22 September. Dinophysis spp. represented up to $24 \%$ of the phytoplankton community on 8 September but less than $1 \%$ on 22 September.

Major differences were found in the grazing response of the different zooplankton species to Dinophysis spp. (Table 2). There were no significant differences in ingestion rate of Euterpina acutifrons and Acartia clausi at different concentrations of Dinophysis. A mean of $3.5 \pm 4.7$ cells female ${ }^{-1} \mathrm{~d}^{-1}($ mean $\pm \mathrm{SE}, \mathrm{n}=20$ ) for $E$. acutifrons and $2.7 \pm 3.3$ cells female ${ }^{-1} \mathrm{~d}^{-1}$ (mean $\pm \mathrm{SE}, \mathrm{n}=19$ ) for $A$. clausi were found. However, in the case of Favella serrata, Oithona nana and Temora longicornis a significant increase in ingestion rate was found at increasing concentrations of Dinophysis spp.

(Table 2, Fig. 4).

Dinoflagellate selection by zooplankton was found also to be species-specific (Fig. 5). Oithona nana did not present any trend in $\alpha_{i}$ for Dinophysis spp. However, Temora longicornis seemed to graze preferably on

\section{September 98}

Dinophysis acuminata

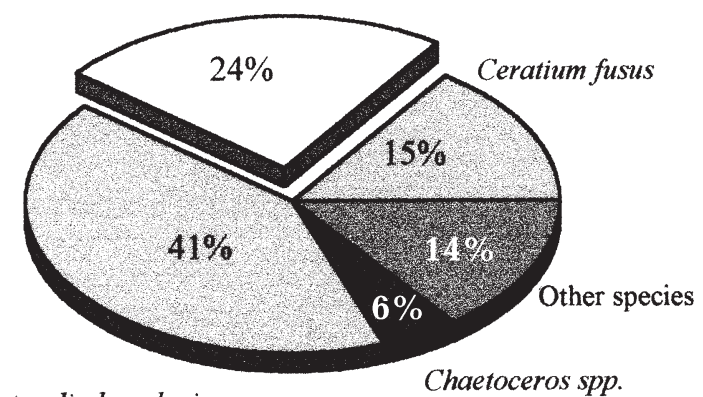

Leptocylindrus danicus

\section{September 98}

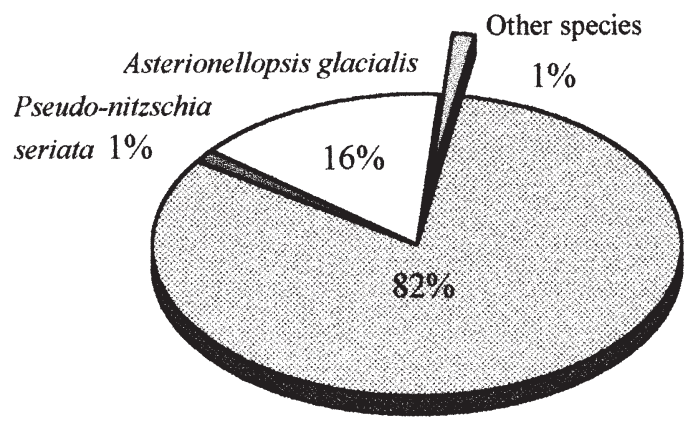

Chaetoceros spp.

Fig. 3. Phytoplankton species composition of the size fraction 20-75 $\mu \mathrm{m}$ used as food in the grazing experiments carried out from samples collected at Stn 3 on 8 September and Stn 2 on 22 September 
Table 2. Summary of 1-way ANOVA comparing zooplankton ingestion rate on Dinophysis spp. as a function of dinoflagellate abundance

\begin{tabular}{|c|c|c|c|c|c|c|c|c|c|c|c|c|c|c|c|c|c|c|c|c|}
\hline \multirow{2}{*}{$\begin{array}{l}\text { Source of } \\
\text { variation }\end{array}$} & \multicolumn{4}{|c|}{ Acartia clausi } & \multicolumn{4}{|c|}{ Euterpina acutifrons } & \multicolumn{4}{|c|}{ Favella serrata } & \multicolumn{4}{|c|}{ Oithona nana } & \multicolumn{4}{|c|}{ Temora longicornis } \\
\hline & $\mathrm{df}$ & MS & $F$ & $\mathrm{p}$ & $\mathrm{df}$ & MS & $F$ & $\mathrm{p}$ & df & MS & $F$ & $\mathrm{p}$ & $\mathrm{df}$ & MS & $F$ & $\mathrm{p}$ & df & MS & $F$ & $\mathrm{p}$ \\
\hline $\begin{array}{l}\text { Dinophysis spp. } \\
\text { abundance }\end{array}$ & 3 & 92.1 & 0.4 & 0.754 & 3 & 36.6 & 0.1 & 0.974 & 3 & 11121.4 & 12.8 & 0.001 & 3 & 1273.2 & 5.9 & 0.007 & 3 & 19721.8 & 7.2 & 0.007 \\
\hline Error & 15 & 229.3 & & & 16 & 511.7 & & & 11 & 869.2 & & & 16 & 216.6 & & & 10 & 2729.1 & & \\
\hline Total & 18 & & & & 19 & & & & 14 & & & & 19 & & & & 13 & & & \\
\hline
\end{tabular}

these dinoflagellates as the phytoplankton concentration declined, whereas Favella serrata showed an increase in $\alpha_{i}$ as the phytoplankton abundance increased.

Fig. 6 shows mean abundance of field populations of Favella serrata, Oithona nana and Temora longicornis during the period that Dinophysis spp. abundance was higher (on 8, 14 and 22 September). O. nana and $T$. longicornis decreased after the bloom of Dinophysis whereas F. serrata concentrations were higher on 14 September and decreased on 22 September.

Fig. 7 shows the relationship between okadaic acid and Dinophysis abundance in the different size fractions and sampling stations obtained on 8 and 14 September. OA was too low to be detected on 22, 28 and 5 October. DTX1 and DTX2 were not detected in any of the size fractions obtained during the period studied. Assuming that the OA present in the $20-100 \mu \mathrm{m}$ size fraction is only due to the Dinophysis spp. cells, it is clear that in the size fractions $>100 \mu \mathrm{m}$ there was more OA than expected from the abundance of Dinophysis spp. cells.

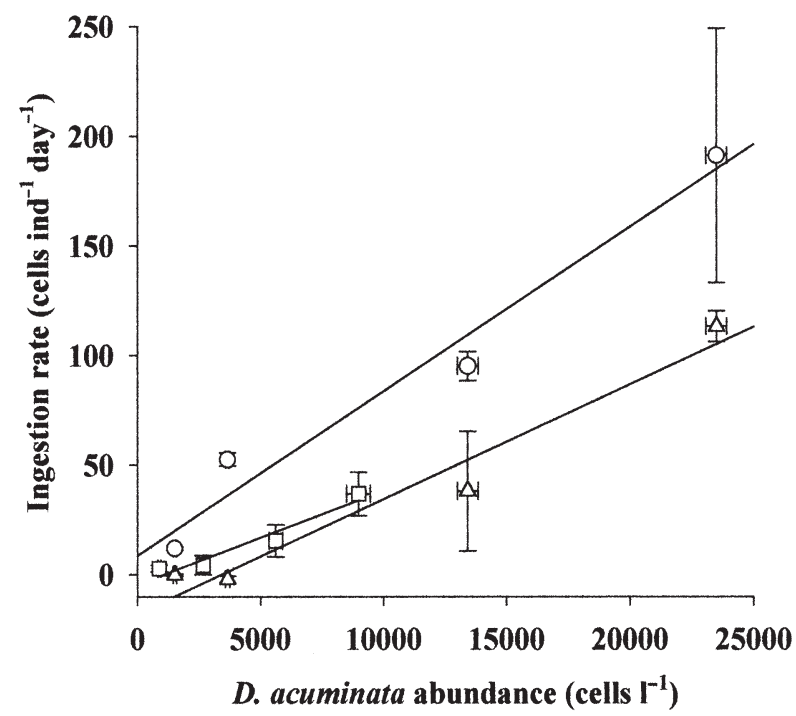

Fig. 4. Ingestion rates of Oithona nana (ם), Temora longicornis $(O)$ and Favella serrata $(\Delta)$ on Dinophysis spp. Slopes are different from zero with a $\mathrm{p}=0.003$ for $O$. nana, $\mathrm{p}=0.025$ for T. longicornis and $\mathrm{p}<0.001$ for F. serrata

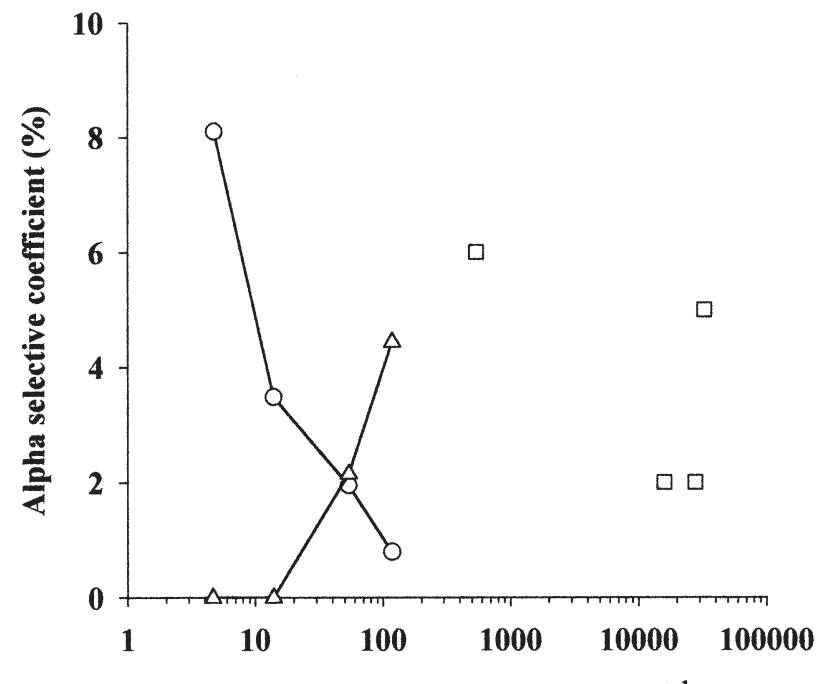

Phytoplankton abundance (cells $\mathrm{ml}^{-1}$ )

Fig. 5. Relationship between $\alpha$ selective coefficient of Oithona nana (ם), Temora longicornis (O) and Favella serrata $(\Delta)$ on Dinophysis spp. and phytoplankton abundance in the grazing experiments

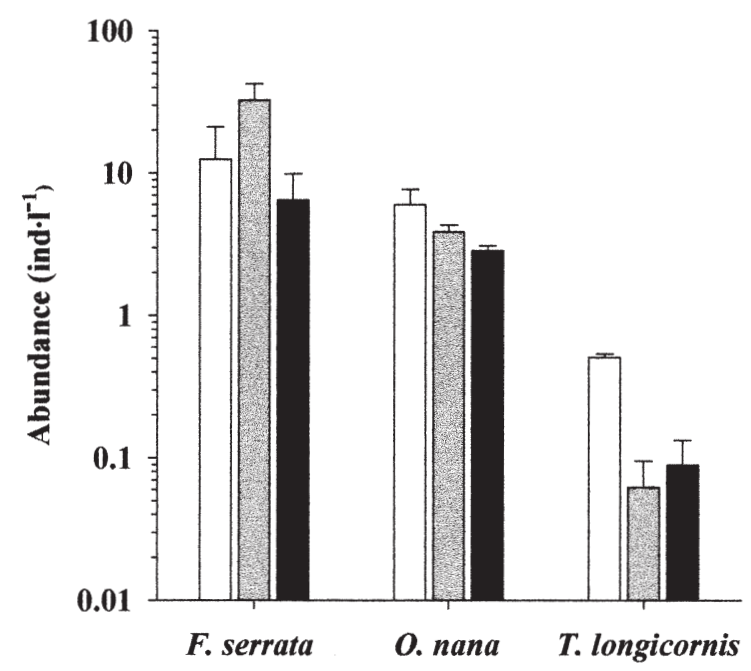

Fig. 6. Mean $\pm \mathrm{SD}$ abundance (ind. $\mathrm{l}^{-1}$ ) of Favella serrata, Oithona nana, Temora longicornis on 8 September (white bars), 14 September (shaded bars) and 22 September (black bars) considering all sampling stations 

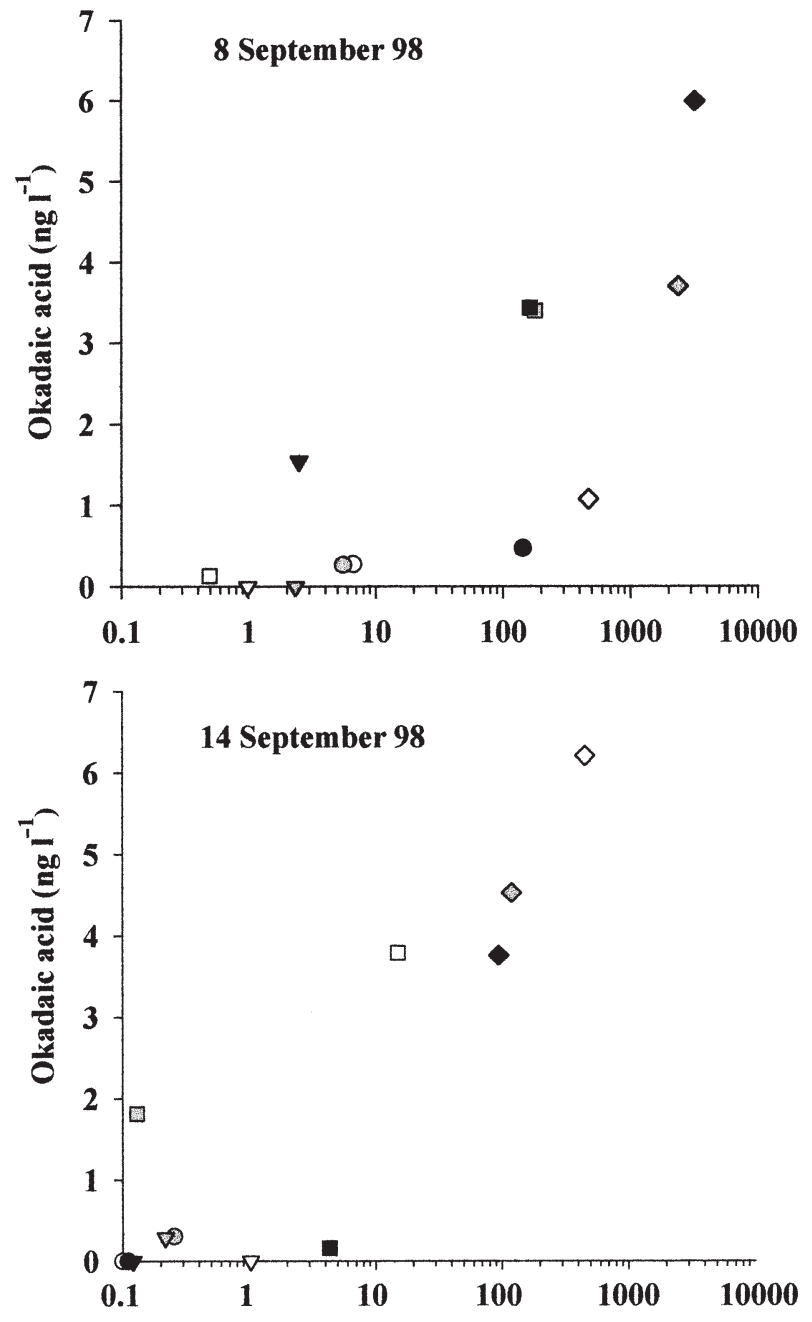

Dinophysis spp. abundance (cells $\mathrm{I}^{-1}$ )

Fig. 7. Relationship between okadaic acid content (in $\mathrm{ng} \mathrm{l}^{-1}$ ) and Dinophysis spp. abundance (in cells $\mathrm{l}^{-1}$ ) of the different

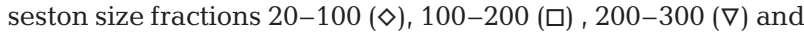
300-1000 (O) $\mu \mathrm{m}$ obtained at each station (white symbols are Stn 1, shaded symbols are Stn 2 and filled symbols are Stn 3) on 8 September and 14 September

Toxicity per cell (pg OA cell ${ }^{-1}$ ) of Dinophysis spp. in the $20-100 \mu \mathrm{m}$ size fraction was estimated considering the OA content and Dinophysis spp. abundance in that fraction. On 8 September a mean \pm SE of $1.8 \pm 0.2$ $(\mathrm{n}=6)$ were found whereas this value increased on 14 September with a mean \pm SE of $30.1 \pm 5.0(n=6)$. From these values we estimated the OA content which does not correspond to Dinophysis cells in the size fraction $>100 \mu \mathrm{m}$, the 'zooplankton OA content' (ZOA). A stepwise multiple regression between the $\mathrm{ZOA}$ and the most abundant zooplankton species was performed for each sampling day. On both dates, Favella serrata abundance showed a significant positive correlation with
ZOA (Fig. 8). Non-significant results were found with the zooplankton species that did not ingest Dinophysis (Acartia clausi and Euterpina acutifrons) but also with species that ingested toxic dinoflagellates (Oithona nana and Temora longicornis).

\section{DISCUSSION}

Although the average OA concentration per cell of Dinophysis showed high variability, it was within the range of variation found in previous studies in the area (Blanco et al. 1995). This variability could result from the variation in the proportion of different Dinophysis spp. and to different physiological states of the cells as the bloom declined. Fernández et al. (2000) found large differences of toxicity per cell between different blooms or even between cells of the same species kept in the laboratory for a few days.

OA found in the seston size fraction $>100 \mu \mathrm{m}$ indicates that OA is inside zooplankton that ingested Dinophysis spp. cells. Results from the grazing experiments suggest that Acartia clausi and Euterpina acutifrons did not ingest Dinophysis spp. cells. The response of the E. acutifrons is similar to the results of Bagøien et al. (1996), who showed that this copepod did not feed on toxic cultures of Alexandrium minutum, even when this dinoflagellate was the only food provided to starving adult females. Several studies describe the feeding response of Acartia spp. to toxic Dinophysis spp. Turner \& Anderson (1983) observed that Dinophysis acu-

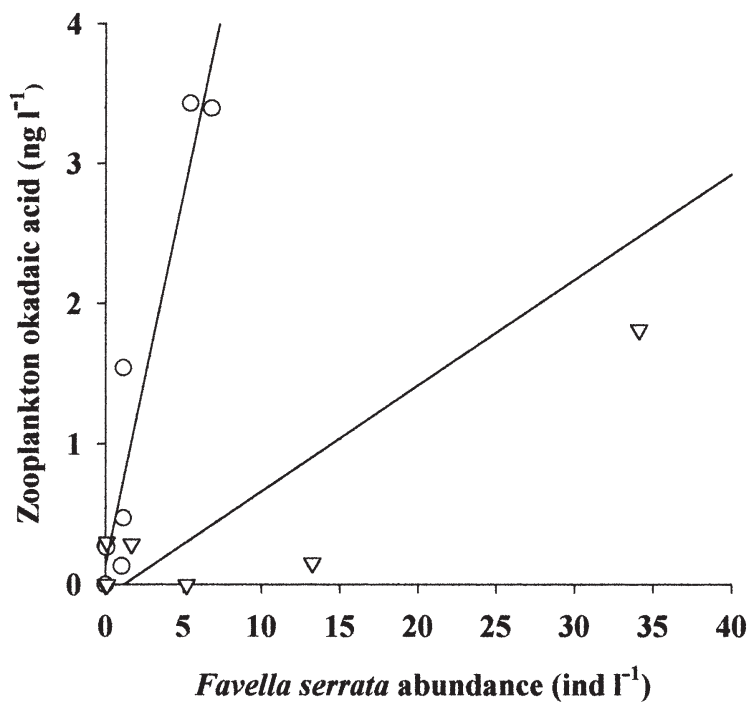

Fig. 8. Relationship between zooplankton okadaic acid content of different seston size fractions and Favella serrata abundance on 8 September $(\nabla)$ and 14 September (O). Slopes are different from zero with a $\mathrm{p}<0.001$ on 8 September and $p=0.001$ on 14 September 
minata was not grazed upon by $A$. clausi, whereas Carlsson et al. (1995) found that $A$. clausi grazed significantly on $D$. acuminata when a 20-75 $\mu$ m concentrated phytoplankton assemblage with a high content of this species was used as food. However, a higher agreement was found in the case of the interaction between A. clausi and Alexandrium tamarense. Several studies have shown that this copepod species grazed on this toxic dinoflagellate (White 1981, Turner \& Anderson 1983, Ives 1985, 1987). Turner et al. (1997) suggested that the lack of co-evolutionary experience in feeding toxic cells could be the reason for the discrepancy in some experimental results. However, Dutz (1998) observed that $A$. clausi females from the German Bight were able to ingest toxic cells of Alexandrium lusitanicum, although the copepods had never been exposed to natural blooms of this Iberian strain.

Our results on the feeding response of Acartia clausi to Dinophysis spp. are in agreement with those obtained by Turner \& Anderson (1983). However, Carlsson et al. (1995) observed that Dinophysis acuminata was one of the dominant phytoplankton species in the phytoplankton assemblage used as food, whereas in our grazing experiment dinoflagellates represented less than $1 \%$ by number of the phytoplankton concentrate. As A. clausi is a selective feeder (Donaghay \& Small 1979) the accompanying phytoplankton might explain the different results found between both experiments.

In contrast with Euterpina acutifrons and Acartia Clausi, Temora longicornis and Oithona nana fed on Dinophysis spp. However, neither species showed a positive correlation with the ZOA observed in their

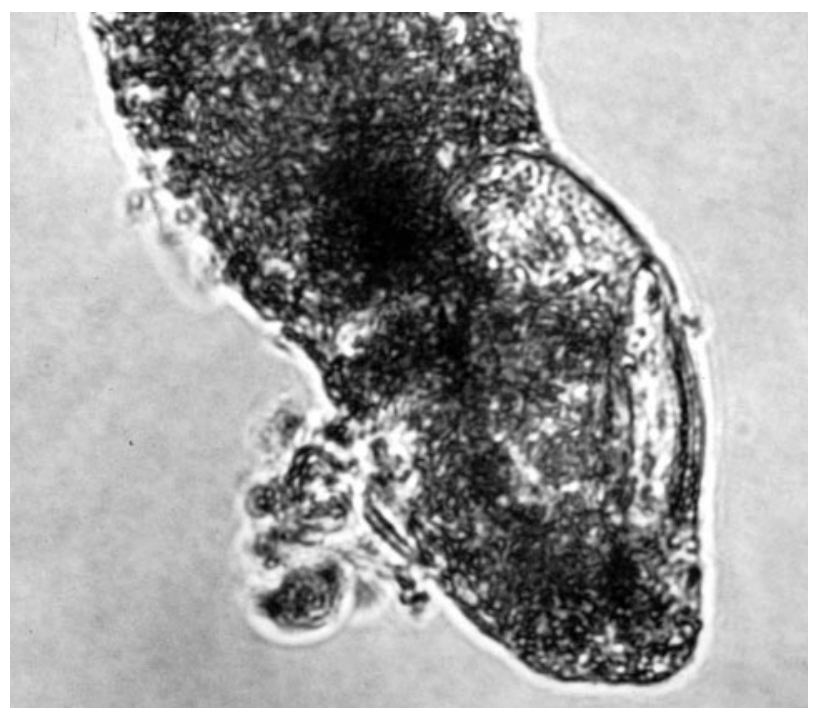

Fig. 9. Pellet of Temora longicornis with undigested Dinophysis spp. cell inside size fraction. This suggests that, although they may eat Dinophysis spp., and could transmit cells in their guts to predators, accumulation and transmission of DSP through the food web by these zooplankton species is not important. At least in the case of $T$. longicornis, copepods may ingest the dinoflagellates but they do not digest them. This is supported by the observation of undigested Dinophysis cells in pellets from T. longicornis incubations (Fig. 9). An alternative explanation could be that population density of both copepod species was not high enough to have an important grazing effect on Dinophysis spp. In fact, population density of both copepod species decreased the following weeks after the bloom (Fig. 6).

Field studies have shown that some tintinnids, especially Favella spp., are often found associated with high Dinophysis spp. densities (Santhanam \& Srinivasan 1996, Maneiro et al. 1998). Experiments show Favella spp. can graze on PSP toxins producing dinoflagellates (Stoecker et al. 1981, Hansen 1989). Results from this study seem to confirm that tintinnids can also ingest dinoflagellates that produce DSP. Moreover, the population density of Favella serrata increased considerably after the Dinophysis bloom, and a reduction was observed when the density of Dinophysis spp. declined (Fig. 6).

Our study also reveals that Favella serrata was able to retain OA. However, the slopes of the regression obtained between ZOA and F. serrata abundance were different on 8 and 14 September. The fact that the concentration of DSP toxins in tintinnids was not found to be a simple function of the abundance might be explained by the selection pattern showed by F. serrata on Dinophysis spp. (Fig. 5). Grazing experiments showed that at high concentrations of Dinophysis spp. (as on 8 September) F. serrata selectively preyed on dinoflagellates, whereas at low Dinophysis spp. densities $(22$ September) it did not graze preferably on dinoflagellates. This agrees with previous results in Ría de Pontevedra, where positive correlation of Favella spp. abundance and Dinophysis acuminata abundance were found only when a threshold of 1750 cells $1^{-1}$ was reached (Maneiro et al.1998).

The high population density reached by Favella serrata, together with an active feeding selection on Dinophysis spp. at high concentrations could be the reason why, in this study, this microzooplankton species accumulate DSP.

The egestion of intact Dinophysis cells in faecal pellets of Temora longicornis could be interpreted as an alternative mechanism of toxin transfer that should be evaluated. These pellets with toxic cells within them can be eaten by coprophagous organisms in the pelagic food web. Alternatively, sedimented pellets can be eaten by a wide community of zooplanktonic 
organisms (ciliates, harpacticoid copepods, etc.) that are abundant on sediments rich in organic matter. Furthermore, the 'toxic pellets' can be eaten by detritivorous bivalves and other benthic species, that also become toxic during intense DSP episodes in the area. In this way, zooplanktonic organisms that do not assimilate the toxic dinoflagellate cells would make toxins from Dinophysis spp. available to bottom dwellers via sedimentation of faecal pellets.

Acknowledgements. We thank T. Wyatt for useful comments on the manuscript, M. Vázquez and E. Ávila for technical support and the crew of RV 'J. M. Navaz' (I.E.O.) and 'Centro para control da Calidade do Medio Mariño' (Xunta Galicia) for helpful assistance. This research was supported by CYTMAR projects MAR95-1179, MAR96-1822 and MAR98-0978, and grants from FPU to I.M., from Fundación Provigo to I.R. and from the Chilean Government to M.F.

\section{LITERATURE CITED}

Bagøien E, Miranda A, Reguera B, Franco JM (1996) Effects of two paralytic shellfish toxin producing dinoflagellates on the pelagic harpacticoid copepod Euterpina acutifrons. Mar Biol 126:361-369

Beaulieu JL, Castonguay $M$, Levasseur M, Grégoire $F$, Michaud S, Bonneau E, Bates SS (1996) Role of PSP (Paralytic Shellfish Poisoning) toxins in an Atlantic mackerel (Scomber scombrus) mortality in Nova Scotia in 1993. Can Ind Rep Fish Aquat Sci 236:1-17

Blanco J, Fernández ML, Mariño J, Reguera B, Míguez A, Maneiro J, Cacho E, Martínez A (1995) From Dinophysis spp. toxicity to DSP outbreaks: a preliminary model of toxin accumulation in mussels. In: Lassus P, Arzul G, Erard-Le Denn E, Gentien P, Marcaillou-Le Baut C (eds) Harmful algal blooms. Lavoisier Publishing, Paris, p 777-782

Boyer GL, Sullivan JJ, Leblanc M, Andersen RJ (1985) The assimilation of PSP toxins by the copepod Tigriopus californicus from dietary Protogonyaulax catenella. In: Anderson DM, White AW, Baden DG (eds) Toxic dinoflagellates. Elsevier Science Publishing Co, Inc, p 407-412

Carlsson P, Granéli E, Finenko G, Maestrini S (1995) Copepod grazing on a phytoplankton community containing the toxic dinoflagellate Dinophysis acuminata. J Plankton Res 17: 1925-1938

Castonguay M, Levasseur M, Beaulieu JL, Grégoire F, Michaud S, Bonneau E, Bates SS (1997) Accumulation of PSP toxins in Atlantic mackerel: seasonal and ontogenic variations. J Fish Biol 50:1203-1213

Donaghay PL, Small LF (1979) Food selection capabilities of the estuarine copepod Acartia clausi. Mar Biol 52:137-146

Dutz J (1998) Repression of fecundity in the neritic copepod Acartia clausi exposed to the toxic dinoflagellate Alexandrium lusitanicum: relationship between feeding and egg production. Mar Ecol Prog Ser 175:97-107

Fernández ML, Reguera B, Ramilo I, Martínez A (2000) Toxinología y contenido tóxico de Dinophysis acuminata, D. acuta y D. caudata de las Rías Gallegas. In: Márquez I (eds) Actas de la VI reunión ibérica sobre fitoplancton tóxico y biotoxinas. Publicaciones de la Consejería de Agricultura y Pesca, Junta de Andalucía, Congresos y Jornados 55, p 127-127
Frost BW (1972) Effects of size and concentration of food particles on the feeding behaviour of the marine planktonic copepod Calanus pacificus. Limnol Oceanogr 17: 805-815

Geraci JR, Anderson DM, Timperi RJ, Aubin DJ, Early GA, Prescott JH, Mayo CA (1991) Humpback whales (Megaptera novaeangliae) fatally poisoned by dinoflagellate toxin. Can J Fish Aquat Sci 46:1895-1898

Hansen PJ (1989) The red tide dinoflagellate Alexandrium tamarense: effects on behaviour and growth of a tintinnid ciliate. Mar Ecol Prog Ser 53:105-116

Hayashi T, Shimizu Y, White AW (1982) Toxin profile of herbivorous zooplankton during a Gonyaulax bloom in the Bay of Fundy. Bull Jpn Soc Sci Fish 48:1673

Ives JD (1985) The relationship between Gonyaulax tamarensis cell toxin levels and copepod ingestion rates. In: Anderson, White, Baden (eds) Toxic dinoflagellates. Elsevier Science Publishing Co, Inc, p 413-418

Ives JD (1987) Possible mechanisms underlying copepod grazing responses to levels of toxicity in red tide dinoflagellates. J Exp Mar Biol Ecol 112:131-145

Landsberg JH, Stidinger KA (1998) A historical review of Gymnodinium breve red tides implicated in mass mortalities of the manatee (Trichechus manatus latirostris) in Florida, USA. In: Reguera B, Blanco J, Fernández ML, Wyatt T (eds) Harmful algae. Xunta de Galicia and IOC of UNESCO Publishers, p 97-100

Lee JS, Igarashi T, Fraga S, Dahl E, Hovgaard P, Yasumoto T (1987) Determination of diarrhetic shellfish toxins in various dinoflagellate species. J Appl Phycol 1:147-152

Maneiro I, D'Aleo O, Guisande C, Reguera B (1998) Interactions between the DSP agent Dinophysis acuminata and the microzooplankton community. In: Reguera B, Blanco J, Fernández ML, Wyatt $\mathrm{T}$ (eds) Harmful algae. Xunta de Galicia and IOC of UNESCO Publishers, p 386-389

Manly BFJ (1974) A model for certain types of selection experiments. Biometrics 30:281-294

Montoya NG, Akselman R, Franco JM, Carreto JI (1996) Paralytic shellfish toxins and mackerel (Scomber japonicus) mortality in the Argentine Sea. In: Reguera B, Blanco J, Fernández ML Wyatt T (eds) Harmful algae. Xunta de Galicia and IOC of UNESCO Publishers, p 417-420

Montoya NG, Reyero MI, Akselman R, Franco JM, Carreto JI (1998) Paralytic shellfish toxins in the anchovy (Engraulis anchoita) from the Argentinian coast. In: Reguera B, Blanco J, Fernández ML Wyatt T (eds) Harmful algae. Xunta de Galicia and IOC of UNESCO Publishers, p 72-73

Okaichi T (1967) Red tides found in and around the Seto Island Sea in 1965. Tech Bull Fac Agricul Kagawa Univ 15:181-185

Reguera B, Bravo I, Fraga S (1990) Distribution of Dinophysis acuta at the time of a DSP outbreak in the rías of Pontevedra and Vigo (Galicia, NW Spain). ICES CM 1990/L:14

Reguera B, Bravo I, Fraga S (1995) Autoecology and some life history stages of Dinophysis acuta Ehrenberg. J Plankton Res 17:999-1115

Santhanam R, Srinivasan A (1996) Impact of dinoflagellate Dinophysis caudata bloom on the hydrography and fishery potentials of Tuticorin Bay, South India. In: Yasumoto T, Oshima Y, Fukuyo Y (eds) Harmful and toxic algal blooms. Intergovernmental Oceanographic Commission of UNESCO, Sendai, p 41-44

Stoecker D, Guillard RRL, Kavee RM (1981) Selective predation by Favella ehrenbergii (Tintinnida) on and among dinoflagellates. Biol Bull 160:136-145

Teegarden GJ, Cembella AD (1996) Grazing of toxic dinoflagellates (Alexandrium spp.) by estuarine copepods: particle selection and PSP toxins in marine food webs. In: 
Yasumoto T, Oshima Y, Fukuyo Y (eds) Harmful and toxic algal blooms. Intergovernmental Oceanographic Commission of UNESCO, Sendai, p 393-396

Turner JT, Anderson DM (1983) Zooplankton grazing during dinoflagellate blooms in a Cape Cod embayment, with observations of predation upon tintinnids by copepods. PSZN I: Mar Ecol 4:359-374

Turner JT, Tester PA (1997) Toxic marine phytoplankton, zooplankton grazers, and pelagic food webs. Limnol Oceanogr 42:1203-1214

Turner JT, Tester PA, Hansen PJ (1998) Interactions between toxic marine phytoplankton and metazoan and protistan grazers. In: Anderson DM, Cembella AD, Hallegraeff

Editorial responsibility: Otto Kinne (Editor), Oldendorf/Luhe, Germany
GM (eds) Physiological ecology of harmful algal blooms. NATO ASI Series, Vol 41, Berlin, p 453-474

Turriff N, Runge JA, Cembella AD (1995) Toxic accumulation and feeding behaviour of the planktonic copepod Calanus firmanchicus exposed to the red-tide dinoflagellate Alexandrium excavatum. Mar Biol 123:55-64

White AW (1980) Recurrence of kills of Atlantic herring (Clupea harengus harengus) caused by dinoflagellate toxins transferred through herbivorous zooplankton. Can J Fish Aquat Sci 37:2262-2265

White AW (1981) Marine zooplankton can accumulate and retain dinoflagellate toxins and cause fish kills. Limnol Oceanogr 26(1):103-109

Submitted: June 21, 1999; Accepted: December 23, 1999 Proofs received from author(s): July 10, 2000 